\title{
Distributions and predator-prey interactions of macaroni penguins, Antarctic fur seals, and Antarctic krill near Bird Island, South Georgia
}

\author{
George L. Hunt, $\mathrm{Jr}^{1}$, Dennis Heinemann ${ }^{1, *}$, Inigo Everson ${ }^{2}$ \\ ${ }^{1}$ Department of Ecology and Evolutionary Biology, University of California, Irvine, California 92717, USA \\ ${ }^{2}$ British Antarctic Survey, Natural Environment Research Council, High Cross Madingley Road, Cambridge CB3 0ET, \\ United Kingdom
}

\begin{abstract}
We studied the distributions, abundances and interactions of macaroni penguins Eudyptes chrysolophus, Antarctic fur seals Arctocephalus gazella, and their zooplankton prey, in particular Antarctic krill Euphausia superba, near Bird Island, South Georgia, South Atlantic Ocean, in February 1986. Simultaneous surveys of marine birds, Antarctic fur seals and Antarctic krill were conducted along a series of transects radiating from the breeding colonies of the vertebrate predators. We examined the relationships between the distributions of predators and their prey with respect to the abundance of krill in the water column and marine habitats near the colonies. Antarctic fur seals and macaroni penguins showed positive correlations with Antarctic krill density across a wide range of spatial scales. Because krill was abundant close to the colony and predator densities decreased with distance due to geometry, distance from colony was a confounding variable. When the influences of distance and direction on predator abundance were factored out, we were able to demonstrate an additional influence of Antarctic krill abundance at measurement scales between 10 and $100 \mathrm{~km}$ for Antarctic fur seals and for macaroni penguins at the scale of 70 to $100 \mathrm{~km}$. Water depth was an important correlate of Antarctic krill and Antarctic fur seal abundances but not of the abundance of macaroni penguins. We found no evidence that the fur seals or macaroni penguins were concentrating their foraging for krill in the vicinity of the shelf-break.
\end{abstract}

\section{INTRODUCTION}

Students of marine birds and mammals have sought to describe and understand the at-sea distributions and abundances of these organisms (e.g. Laws 1977, Brown 1980, Hunt \& Schneider 1987, Hunt 1990). In early studies, the measurement of prey abundance at appropriate scales was not feasible, and investigators relied on the measurement of physical features of the ocean to describe the marine habitats used by birds and mammals. The implicit assumptions in these studies were that prey availability varied between the habitats described, and that birds or mammals selected those habitats where prey were most profitably acquired. The possibility of making continuous measurements of prey distributions and abundances now

- Present address: Manomet Bird Observatory, PO Box 936, Manomet, Massachusetts 02345, USA permits the study of the relationships between predator and prey abundance over a variety of spatial scales.

Quantitative studies of the relationships between the at-sea distribution and abundance of marine mammals and the distribution and abundance of their prey are few, possibly due to the generally low at-sea densities of marine mammals. At the scale of tens to hundreds of $\mathrm{km}$, there is evidence that marine mammals concentrate where their prey is predictably abundant (e.g. Brodie et al. 1978, Nerini 1984, Oliver et al. 1984, Au \& Pitman 1986). In the Antarctic, there have been no quantitative studies of the joint pelagic distributions of marine mammals and their prey. Inferences concerning the coincidence of the distributions of the great whales and Antarctic krill Euphausia superba have been attempted (Harmer 1931, Hardy \& Gunther 1935, Mackintosh 1965, Laws 1977, Everson 1984), but these studies lacked simultaneous determination of prey resources (see also Plötz et al. 1991, Ribic et al. 1991). 
Factors influencing the at-sea distribution of Antarctic fur seals Arctocephalus gazella are little known. Ensor \& Shaughnessy (1990) found them concentrated over a small rise on the Kerguelen Plateau, and Fraser et al. (1989) and Ribic et al. (1991) reported fur seal use of the marginal ice zone in winter. To our knowledge, there have been no quantitative investigations of the distributions and abundances of marine mammals and their prey that have used continuous, simultaneous records of the abundances of both a species of marine mammal and its prey.

Data on the distributions and abundances of marine birds as a function of prey abundance are accumulating, but there is considerable variation in the strength of the observed correlations. The correlations are scale dependent, with correlations usually being stronger at larger scales of measurement (Schneider \& Piatt 1986. Heinemann et al. 1989, Erikstad et al. 1990, Hunt et al. 1990). In addition, the strength of correlations appears to differ between prey types, with correlations between birds and schooling fish such as capelin Mallotus villosus or surface swarming plankton (McClatchie et al. 1989 ) being stronger, often at relatively smaller measurement scales (e.g. Schneider \& Piatt 1986, Erikstad et al. 1990), than correlations with small, mid-water dwelling zooplankters (e.g. Hunt et al. 1990). Woodby (1984) and Hunt et al. (1990) have hypothesized that detection of the highest density subsurface prey patches by marine birds may be costly in terms of search time, and that use of areas where the overall availability of prey is adequate may be a cost effective foraging strategy (contra arguments against satisficing; Stephens \& Krebs 1986 , p. 180). In the Bering Sea, correlations between least auklets Aethia pusilla and their copepod prey are usually most obvious at large measurement scales (Hunt \& Harrison 1990, Hunt et al. 1990). In the Southern Ocean, correlations between avian predators and krill have been variable in strength. In Bransfield Strait, Obst (1985) found that the presence of high numbers of birds was a good indicator of the presence of Antarctic krill, but he was unable to predict bird density on the basis of either the relative abundance or the depth of krill swarms. Heinemann et al. (1989), working in the same region, also found that the presence of 2 species of seabirds, cape petrels Daption capensis and Antarctic fulmars Fulmarus glacialoides, was associated with the presence of Antarctic krill swarms at the scale of nautical miles, but only for Adélie penguins Pygoscelis adeliae and cape petrels were predator numbers significantly correlated with Antarctic krill density. Correlations between predators and prey were identified over a range of spatial scales from nautical miles to hundreds of nautical miles with the strongest correlations occurring at the larger scales. Near Prydz Bay, Ryan \& Cooper
(1989) showed that birds were more abundant near oceanographic stations where krill was abundant. Both alcids (Hunt \& Harrison 1990, Hunt et al. 1990) and penguins (Fraser et al. 1989) respond to variations in the vertical distribution of prey.

When predators are constrained in foraging by the need to return periodically to a central place such as a breeding colony, that location will determine the foraging areas that are accessible (Hamilton \& Watt 1970 , Orians \& Pearson 1979). Recent work suggests that interspecific and intraspecific competition for food in the vicinity of colonies may play a part in the regulation of seabird and seal reproductive performance (Whittam \& Siegel-Causey 1981a, b, Gaston et al. 1983, Furness $\&$ Birkhead 1984, Laws 1984, Croxall et al. 1985a, Hunt et al. 1986). Thus, data on the spatial relationship of predators to prey at the foraging grounds are useful for the interpretation of the impact of competition and prey fluctuations on the reproductive performance of calonially breeding predators (Croxall et al. 1984a).

In this study, we sought information on the spatial distributions and abundances of 2 species of predators, Antarctic fur seals and macaroni penguins Eudyptes chrysolophus, and their prey, Antarctic krill. Our study was conducted in the vicinity of one of the largest breeding concentrations of seabirds and Antarctic fur seals in the Antarctic, the colonies at the northwest tip of South Georgia and its nearby islands (Bonner 1981, Croxall et al. 1984b). Based on past work and our experience, we anticipated that krill might be more common on the north side of the island, where historic records of whale harvest have been interpreted to indicate that krill was particularly abundant (Everson 1984). We also expected we might find krill concentrated near the shelf slope (Makarov et al. 1988), a habitat where we and others have found concentrations of foraging birds (e.g. Ainley \& Jacobs 1981, Powers \& Brown 1987, Veit \& Hunt in press). At the time the survey was designed, we anticipated that marine predators, such as seals and penguins that have access to a large proportion of the water column, would be efficient at finding their prey. Therefore, when the effects of travel distance from the colony were accounted for, we expected significant, strong correlations between these predators and their prey, as predicted from foraging theory (e.g. Milinski \& Parker 1991).

\section{METHODS}

Study site and species. We chose as our study site the waters around the islands at the northwest tip of South Georgia, in the Atlantic sector of the Southern Ocean. The center of our survey area was between Bird Island and the Willis Islands (Fig. 1). The area is characterized 


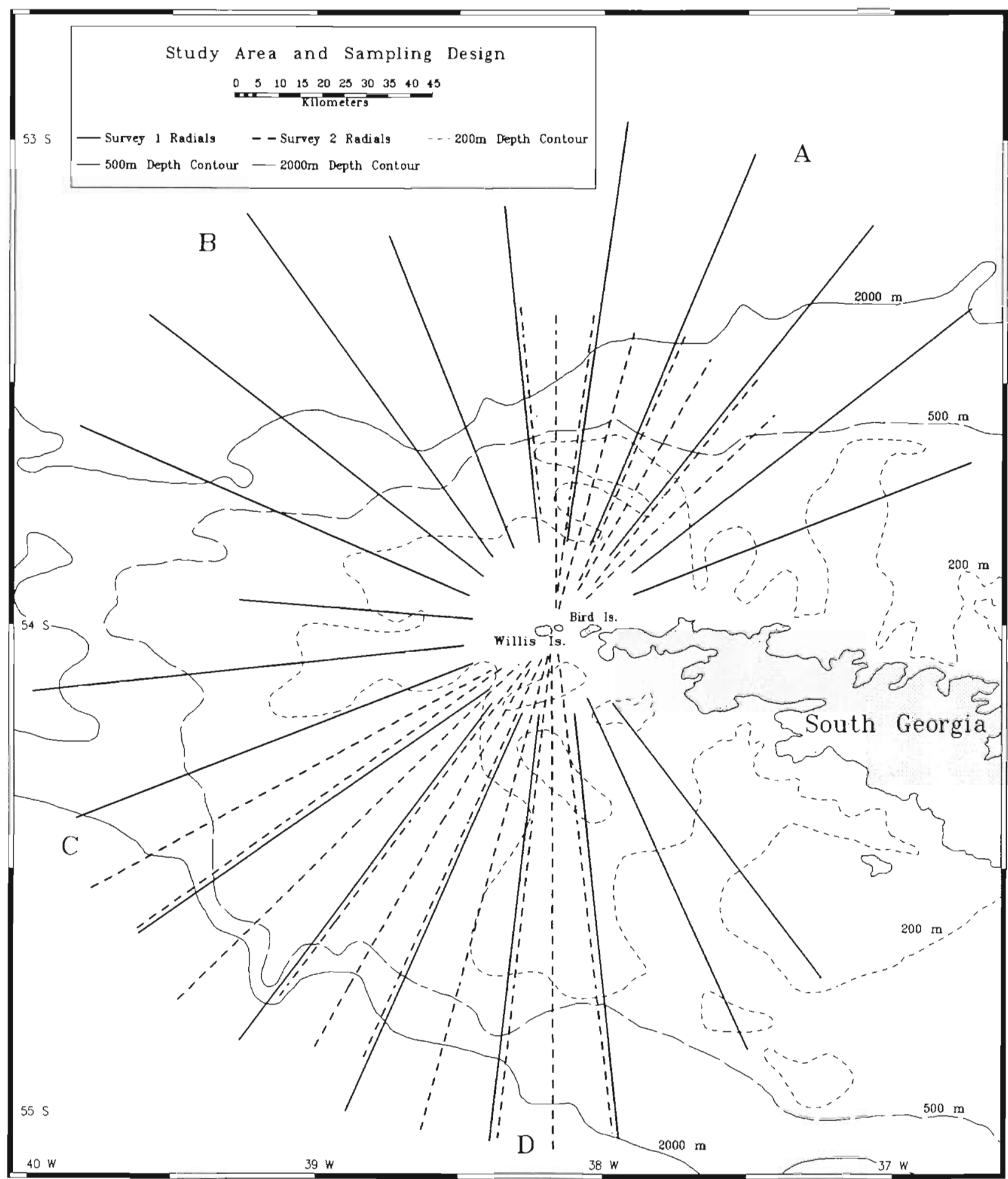

Fig. 1. Study area and sampling design. Radials were centered on the seabird and Antarctic fur seal colonies on the Willis Islands, Bird Island and the tip of South Georgia in the Atlantic sector of the Southern Ocean. The first set of 20 radials, $15^{\circ}$ apart, were sampled during Survey 1 , and the second set of $18,7.5^{\circ}$ apart, were sampled during Survey 2 . The Survey 1 radials were separated into 4 sectors, $A$ to $D$ of 5 radials each, for analyses 
by a broad shelf, 90 to $130 \mathrm{~km}$ wide, to the south and west, and a narrow, 35 to $55 \mathrm{~km}$ wide shelf to the north. The islands of this region support very large breeding colonies of 2 subsurface-foraging krill predators, Antarctic fur seals and macaroni penguins. Thus, by working near their colonies, we were assured of obtaining a large number of observations of the at-sea distributions of these predators. Antarctic fur seals and macaroni penguins were chosen as the focal predator species because we had information from concurrent work on Bird Island on the foraging ranges, dive depths, and diets of these 2 species. Based on energy and time budgets (Croxall et al. 1984a, Kooyman et al. 1986), we calculated that the average maximum foraging ranges of the fur seals and penguins were 150 and $125 \mathrm{~km}$, respectively, distances within a practical survey radius centered on the colonies. Depth of dive data showed that both predator species were capable of diving to depths between 80 and $100 \mathrm{~m}$, although most dives were likely to be to depths shallower than 40 to $60 \mathrm{~m}$ (Croxall et al. 1985b, 1988). Antarctic krill constituted, by mass, $69 \%$ of Antarctic fur seal and $98 \%$ of macaroni penguin diets (Croxall et al. 1985a), and thus there was a single prey species on which we could focus. Together, these predators constituted a major portion of the individuals and biomass of the seabirds and pinnipeds that breed in the area (Croxall \& Prince 1981, Laws 1984). Thus, information on their foraging ecologies would provide an indication of the area over which the avian and pinniped residents of the area's colonies might have an important impact on prey resources and marine trophic webs.

Sampling design. To determine the at-sea distributions and abundances of Antarctic fur seals, macaroni penguins and Antarctic krill, we collected data along radial transects, hereafter referred to as 'radials', centered on a point ca $0.5 \mathrm{~km}$ south of Trinity Island in the Willis Islands $\left(54^{\circ} 00.3^{\prime} \mathrm{S}, 38^{\circ} 10.2^{\prime} \mathrm{W}\right.$; Fig. 1), which represented the approximate 'center of mass' of the macaroni penguin colonies (J. P. Croxall pers. comm.). Hereafter, this survey center will be referred to as the 'colony'. We conducted 2 sets of surveys. Survey 1 , from 4 to 13 February 1986 , consisted of 20 radials spaced $15^{\circ}$ apart and arrayed in 4 sectors around the colony (Fig. 1). Each sector was sampled in $2 \mathrm{~d}$, in the $\operatorname{order} \mathrm{D}, \mathrm{A}, \mathrm{C}, \mathrm{B}$. Survey 2, designed after the completion of Survey 1 to investigate more intensively areas where Antarctic krill and its predators were particularly abundant, was run from 16 to 23 February. On Survey 2, we sampled 18 radials that were $7.5^{\circ}$ apart (Fig. 1).

To encompass the major portion of the foraging range of both the Antarctic fur seals and macaroni penguins, our radials in Survey 1 extended 98 to $120 \mathrm{~km}$ (mean $113 \mathrm{~km}$ ) from the colony; the survey of one radial in Sector $C$ was terminated at $72 \mathrm{~km}$ from the colony because of bad weather. Survey 1 was designed so that the inner ends of the radials commenced 18 to $21 \mathrm{~km}$ (mean $20 \mathrm{~km}$ ) from the colony, thereby lessening the impact of counts of commuting seals and penguins on our results. Based on the results of Survey 1, during the course of which we observed large amounts of krill close to the colonies, radials in Survey 2 were begun closer to the colonies. In Survey 2, radials on the south began at 5.5 to $16.7 \mathrm{~km}$ (mean $9.3 \mathrm{~km}$ ), and extended to 103 to $118 \mathrm{~km}$ from the colony. Radials on the north began at 3.7 to $12.9 \mathrm{~km}$ (mean $9.3 \mathrm{~km}$ ) and extended to 70 to $74 \mathrm{~km}$ (mean $72 \mathrm{~km}$ ) from the colony. In Survey 1 , $2 \frac{1}{2}$ radials were run each day; one-third started at the colony, one-third at the outer and one-third half way between the outer and inner ends. This design assured that there was no systematic bias in the time of day in our surveys. In Survey 2, 2 or 3 radials were sampled each day, alternating between adjacent pairs of radials on the north and adjacent pairs on the south of the islands. In both Surveys 1 and 2, inner ends of radials were over shallow shelf waters, ca 100 to $300 \mathrm{~m}$ deep. In Survey 1, most outer ends of radials were over depths of 1900 to $4000 \mathrm{~m}$; 4 radials ended over depths of 300 to $350 \mathrm{~m}$. In Survey 2, most outer ends of radials were over water 1500 to $4000 \mathrm{~m}$ deep; one ended over water $700 \mathrm{~m}$ deep.

Sampling techniques. We counted seabirds and Antarctic fur seals continuously during daylight hours from the bridge wing (eye height $10 \mathrm{~m}$ above water) of the British Antarctic Survey's RRS 'John Biscoe' when travelling at a mean speed of $18.5 \mathrm{~km} \mathrm{~h}^{-1}$ and with at least $300 \mathrm{~m}$ visibility. Observations were made from the leeward side of the ship except when low sun angle and consequent glare reduced the ability to see or identify individual species. Teams of 2 observers counted all species of seabirds and marine mammais seen within an arc $300 \mathrm{~m}$ from directly ahead of the ship to $90^{\circ}$ to the side. One observer usually concentrated on Antarctic fur seals, penguins and other seabirds on the water, while the second observer counted seabirds in flight. A third person entered data directly into a microcomputer (Updegraff \& Hunt 1985). Later we combined, on the basis of time, our data with information from other aspects of the project to form a single data base.

The distribution and density of zooplankton were estimated using a Simrad EK400 echosounder operating at $120 \mathrm{kHz}$. The transceiver operated through a hull-mounted transducer at a depth of $5 \mathrm{~m}$ below the surface. The instrument settings were as follows:

$\begin{array}{ll}\text { Parameter } & \text { Value } \\ \text { Pulse duration } & 1 \mathrm{~ms} \\ \text { Pulse repetition } & 21 \mathrm{~min}^{-1} \\ \text { Frequency } & 120 \mathrm{kHz}\end{array}$




$\begin{array}{ll}\text { Source level } & 215.2 \mathrm{~dB} / / 1 \mu \mathrm{Pa} / 1 \mathrm{~m} \\ \text { Voltage response } & -100.0 \mathrm{~dB} / / 1 \mathrm{~V} / 1 \mu \mathrm{Pa} \\ \text { Calibration factor ' } \mathrm{C} \cdot & -47.1 \mathrm{~dB} \\ \text { Range } & 0 \text { to } 250 \mathrm{~m}\end{array}$

The echosounder was calibrated at South Georgia; the water temperature was close to that during the period of the observations $\left(1.5^{\circ} \mathrm{C}\right)$. No correction for temperature (BIOMASS 1986) was applied. Antarctic krill and other zooplankton were sampled using an RMT8 net after dark to minimize loss due to avoidance (Everson \& Bone 1986). The resultant krill size-frequency distributions were used to estimate target strength using published equations (BIOMASS 1986). Recent adjustments of the target strength (Everson et al. 1990, Foote et al. 1990) were not incorporated here because, at the time of the preparation of this paper, a widely accepted target strength to size relationship was not available (SC-CAMLR 1990). Krill density values reported here are therefore indices of abundance. Analyses of the echo-sounding and net data showed that the vast majority of echo-soundings were of Antarctic krill, but some particular echo traces are still being analyzed to determine their origin. Throughout this paper we refer to all zooplankton biomass that was recorded by the echosounder as Antarctic krill biomass despite the fact that some small amount may have belonged to other species. In addition to data on predator and prey abundances, we recorded local time, position and water depth. From the recorded positions we calculated distances to the colony.

The numbers of individuals observed per linear nautical mile (n mile) were our basic measures of densities for Antarctic fur seal and macaroni penguin. As a measure of Antarctic krill density, we estimated the number of Antarctic krill in a $1 \mathrm{~m}^{2}$ column from $10 \mathrm{~m}$ deep to the bottom or $200 \mathrm{~m}$, whichever was shallower, averaged over $1 \mathrm{n}$ mile intervals of transect line. One $n$ mile was chosen to be consistent with previous data sets. Predator numbers were summed over the same n mile intervals.

Statistical analyses. We used Analysis of Variance (ANOVA), Analysis of Covariance (ANCOVA), and correlation to analyze patterns of abundances of predators and prey with environmental factors and each other. All statistical analyses were completed using SYSTAT (Wilkinson 1986). Abundance estimates of predators and Antarctic krill within the n mile sampling units, or the means of estimates pooled over larger areas (e.g. portions of radials, entire radials, sectors) were highly non-normal, and could not be normalized consistently by transformation (e.g. log transformation). Therefore, we conducted all analyses on rank-transformed (i.e. ranked) data, a technique that has been shown to give robust results (see Conover 1980, p. 337).
Survey 1: The association between predators and Antarctic krill was assessed using correlation analysis across a wide range of spatial scales. Because the correlations at any 2 scales were not independent, we report the significance only at the scale of whole radials. This scale was chosen because it was the smallest scale at which the sampling units were clearly spatially and temporally independent. We assessed the effect of Antarctic krill density on predator abundance by including Antarctic krill as a linear term ('Krill') in an ANCOVA model, with the categorical variables 'Direction' and 'Distance' included, at those scales deemed most appropriate from the correlation analysis. 'Direction' of survey had 4 levels (sectors A, B, C and D; see Fig. 1), and 'Distance' from colony had 5 levels (18.5 to 37,37 to $55.5,55.5$ to 74,74 to 92.5 and $>92.5$ $\mathrm{km}$ ). Sectors were part of the survey design and the distance intervals were chosen by reaching a compromise between resolution (the number of intervals) and within-interval sampling effort (length of interval).

To test the hypothesis that krill and its predators would concentrate over the shelf-break, we used ANCOVA to determine the additional variance explained by water depth once the influences of distance from colony and direction were removed. Depth was analyzed in 2 ways. First, we used the depth profile along each radial to define segments corresponding to (1) the relatively flat, shallow areas close to the island ('continental shelf'), (2) the zone of deeper, steep bottom contours ('continental slope'), and (3) the relatively flat, very deep areas farthest from the island ('slope base'). Because the definition of these zones primarily depended on the position of the continental slope, the cutoffs between shelf and slope ('shelf break'), and slope and 'base of slope' occurred at different distances from the colony and different depths on different radials. Shelf-break depths varied from 145 to $300 \mathrm{~m}$ and were located from 35 to $93 \mathrm{~km}$ from the colony. Slope-base depths varied from 950 to $3900 \mathrm{~m}$ and were located from 50 to $107 \mathrm{~km}$ from the colony. The effect of this categorical variable, 'Depth-Realm', was determined using ANCOVA with Direction and Distance included, where Distance was not the categorical variable described above but a linear covariate; the values of Distance were the mean distances to the colony for each Depth-Realm unit. Second, we used ANCOVA to analyze depth directly in conjunction with the categorical variables Direction and Distance. The mean depths in distance intervals were then used as a linear covariate, 'Depth' in this model.

Survey 2: We used 2-way ANOVAs to estimate simultaneously the effects of 'Side' of survey (2 levels: North and South) and 'Distance' from colony (4 levels) on the abundances of Antarctic krill, macaroni penguins and Antarctic fur seals. Because the radials 
extended different distances from the colony on each side, the distance intervals were defined separately for North (5 to 26, 27 to 41,42 to 56,57 to $74 \mathrm{~km}$ ) and South ( 3 to 37,38 to 65,66 to 93,94 to $118 \mathrm{~km}$ ). Because the distance intervals were different on the 2 sides of the colony, we used nested ANOVA to analyze the effects of direction (Side: North vs South) and Distance (4 levels) from the colony. The effects of the factors Depth-Realm and Depth were not analyzed for the Survey 2 data. We assessed the effect of Antarctic krill density on predator abundances by including Antarctic krill as a linear term ('Krill') in an ANCOVA model, with Distance included in the model. Because of the large differences in the distributions and overall abundance of Antarctic krill on the 2 sides of the colony, separate ANCOVAs were used for each side.

Biases. The strongest and most accurate estimates of the concordance of predator and prey distributions should be those obtained when observations cover completely the times and places that the majority of predators use for foraging, and which record completely the distribution and abundance of prey available to the predators. Because our sampling scheme could not achieve this ideal, our findings may underestimate the extent to which prey distribution and abundance influence the distributions and abundances of foraging predators.

Our estimates of predator abundance were made during the day, but most Antarctic fur seals (Croxall et al. 1985b) and many macaroni penguins (Croxall et al. 1988) forage at night. Because we were rarely able to ascertain if porpoising Antarctic fur seals or macaroni penguins were indeed commuting, or if those animals not apparently travelling were in fact feeding, we chose to use total counts as our measures of predator abundances. Because technological limitations prevented us from detecting zooplankton shallower than $10 \mathrm{~m}$, and because Antarctic krill go through daily vertical migrations (Everson 1983), we chose to use krill density averaged from $10 \mathrm{~m}$ to the bottom or $200 \mathrm{~m}$ whichever was shallower, as an index of the total Antarctic krill potentially available to predators. We did not use a more restricted data set because we could not find one that consistently improved correlations.

Our results may not reflect accurately the relationships between Antarctic fur seals or macaroni penguins and their prey because we (1) missed many of the feeding predators by sampling only during the day, (2) contaminated our estimates of predator distributions and abundances with commuting individuals, (3) included Antarctic krill too deep to be immediately available to predators, and (4) failed to include the krill most easily available to the predator, namely those Antarctic krill shallower than $10 \mathrm{~m}$.

We performed tests to assess the possibility that the first 3 factors described above severely biased our results. We compared Spearman rank predator-prey correlations at the $\mathrm{n}$ mile scale (1) for dawn and dusk (before 06:30 and after 18:30 h) versus the rest of the day, (2) using the abundance of non-travelling predators (presumed feeding) versus those porpoising (presumed commuting) and (3) using Antarctic krill densities mostly within the foraging depth ranges of the predators (less than $60 \mathrm{~m}$; Croxall et al. 1985b, 1988 ) versus mostly below their range (greater than $60 \mathrm{~m}$ ). In each case, the paired correlations were compared using the Wilcoxon signed-rank test, and were meant to assess how strong these potential biases were, rather than to eliminate or correct the biases through statistical control.

\section{RESULTS}

We completed $1780 \mathrm{~km}$ of simultaneous surveys of marine birds, Antarctic fur seals and Antarctic krill along 20 radials during Survey 1 ; an additional $1554 \mathrm{~km}$ along 18 radials were sampled in Survey 2 (Fig. 1). At the time of the surveys, macaroni penguins and Antarctic fur seals were rearing offspring in the study area (J. Croxall pers. comm.). Thus, many individuals of the species observed were acting as centralplace foragers, that is they were required to return to the colony on a regular basis to provision their young. An unknown portion of the individuals observed were non-breeding animals and thus were not required to return to the colonies.

\section{Survey 1}

Distributional patterns. Most of the largest concentrations of Antarctic krill were close to the inner ends of the radials, especially to the south of the colony (Fig. 2). Antarctic krill density showed a roughly linear decline out to $92 \mathrm{~km}$ and then a slight rise in the outermost distance ring (Table 1) Antarctic fur seals and macaroni penguins had approximately similar distributions to those of Antarctic krill, with Antarctic fur seals extending farther seaward than macaroni penguins. Macaroni penguin and Antarctic fur seal abundances, on the south side of the colony, decreased abruptly by 3 to 7 times from the 1 st to 2 nd distance ring, and then showed a gradual, approximately linear, decline to the ends of the radii (Table 1). On the north side of the colony, the abundance of Antarctic fur seals was bimodal with roughly equal peaks in the 1 st and 4 th distance rings. The general absence of macaroni penguins and the diminished number of Antarctic fur seals at the outer ends of the radials are evidence that the 

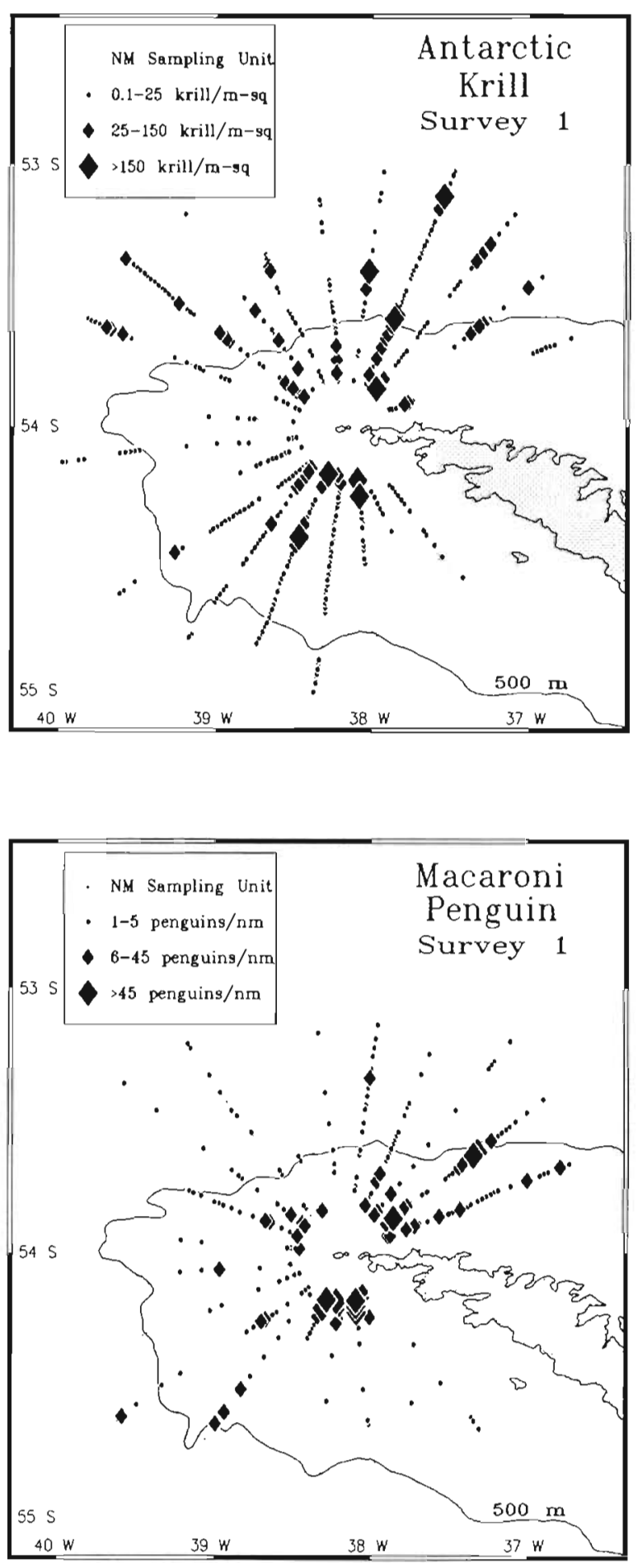

radials were sufficiently long to encompass most of the foraging ranges of breeding individuals of both species.

Predator-krill correlations. Previous studies have found that spatial scale has a strong effect on the correlation between predator and prey abundance, with the strongest relationships usually being detected at large scales (Obst 1985, Schneider \& Piatt 1986,

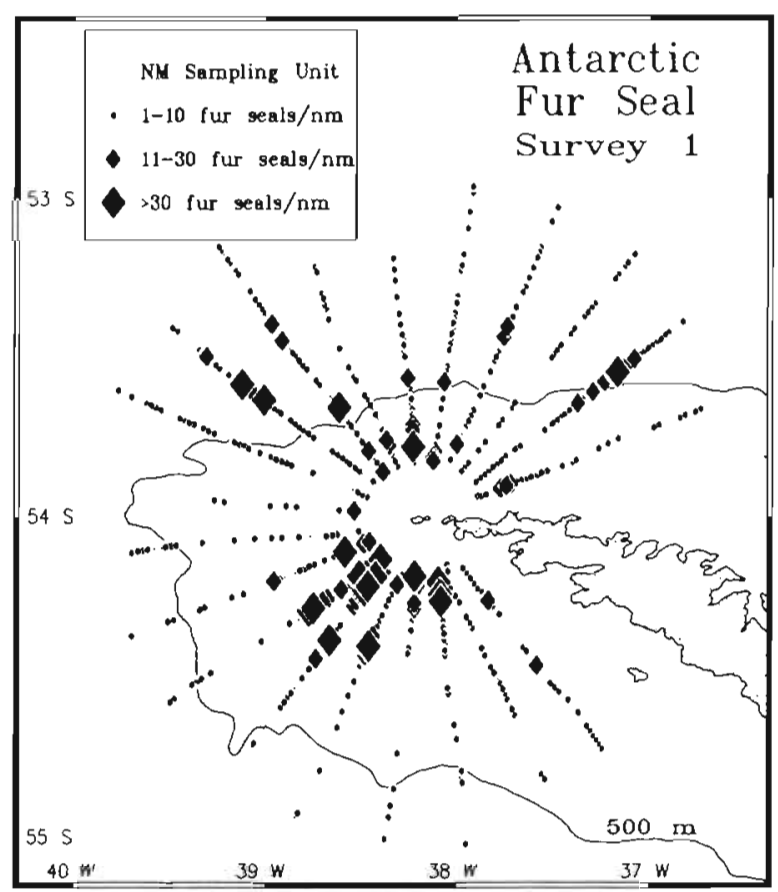

Fig. 2. Distribution maps of Antarctic krill (number $\mathrm{m}^{-2}$ ) and predators from Survey 1. Data were averaged over $1 \mathrm{n}$ mile intervals (no. per $n$ mile) for display. Abundances of zero are indicated by single points, and densities greater than zero are shown by diamonds, the sizes of which are proportional to the logs of the abundance

Heinemann et al. 1989, Erikstad et al. 1990, Hunt et al. 1990). We calculated rank correlations between krill density and predator abundances over a range of spatial scales from the $n$ mile sampling units to whole sectors (Table 2). Correlations for macaroni penguins were strongest at the largest scale and decreased monotonically as scale decreased. Correlations of 
Table 1 Mean abundances of predators and prey, and sampling effort during Survey 1, by Sector (Direction) and Distance from colony

\begin{tabular}{|c|c|c|c|c|}
\hline & $\begin{array}{c}\text { Effort } \\
(\mathrm{km})\end{array}$ & $\begin{array}{l}\text { Macaroni } \\
\text { penguins } \\
\left(\text { no. } \mathrm{km}^{-1}\right)\end{array}$ & $\begin{array}{l}\text { Antarctic } \\
\text { fur seals } \\
\left.\text { (no. } \mathrm{km}^{-1}\right)\end{array}$ & $\begin{array}{c}\text { Antarctic } \\
\text { krill } \\
\left(\text { no. } \mathrm{m}^{-2}\right)\end{array}$ \\
\hline \multicolumn{5}{|l|}{ Sector } \\
\hline$A$ & 468 & 2.8 & 3.2 & 13.6 \\
\hline $\mathrm{B}$ & 442 & 0.9 & 3.5 & 6.5 \\
\hline C & 442 & 0.6 & 4.3 & 3.7 \\
\hline $\mathrm{D}$ & 428 & 3.8 & 5.2 & 10.9 \\
\hline \multicolumn{5}{|c|}{ Distance from colony } \\
\hline 18 to $37 \mathrm{~km}$ & 335 & 6.9 & 11.2 & 16.3 \\
\hline 38 to $55 \mathrm{~km}$ & 363 & 1.0 & 3.7 & 11.9 \\
\hline 56 to $74 \mathrm{~km}$ & 353 & 1.7 & 2.1 & 5.5 \\
\hline 75 to $92 \mathrm{~km}$ & 337 & 0.6 & 2.8 & 3.4 \\
\hline 93 to $120 \mathrm{~km}$ & 392 & 0.2 & 1.1 & 6.8 \\
\hline
\end{tabular}

Table 2. Rank correlations between krill density and predator abundance at different spatial scales during Survey 1

\begin{tabular}{|lrccc|}
\hline Scale & $\mathrm{n}$ & $\begin{array}{c}\text { n miles } \\
\text { per unit }\end{array}$ & $\begin{array}{c}\text { Macaroni } \\
\text { penguin }\end{array}$ & $\begin{array}{c}\text { Antarctic } \\
\text { fur seal }\end{array}$ \\
\hline Sectors & 4 & 231 to 253 & 0.80 & -0.40 \\
Radial-pairs & 10 & 72 to 104 & 0.66 & 0.52 \\
Radials & 20 & 40 to 54 & 0.46 & 0.49 \\
1/2-Radials & 40 & 15 to 28 & 0.27 & 0.56 \\
1/s-Radials & 109 & 5 to 13 & 0.19 & 0.50 \\
1/10-Radials & 202 & 3 to 7 & 0.19 & 0.37 \\
n mile pairs & 476 & 2 & 0.17 & 0.29 \\
n miles & 962 & 1 & 0.11 & 0.19 \\
\hline
\end{tabular}

Antarctic fur seals and Antarctic krill, however, were greatest at intermediate scales, very low at small scales and negative at the scale of sectors. At the scale of whole radials, the smallest scale with statistically independent sampling units, both predators showed significant positive correlations between their abundances and that of krill (both p-values $<0.025$ ).

The decrease in the macaroni penguin-Antarctic krill correlation from its maximum at the scale of sectors to very low levels at sampling scales smaller than radials suggests the possibility that an association at the largest scale was responsible for the correlations at smaller scales. However, Antarctic krill density explained a significant proportion of the variance in macaroni penguin abundance at the scale of whole radials even with the effect of Direction removed (ANCOVA: Direction, df $=3, \mathrm{p}=0.014$; Krill, $\mathrm{df}=1$, $\mathrm{p}=0.030$; interaction, $\mathrm{df}=3, \mathrm{p}=0.024$; error, $\mathrm{df}=12$ ). The interaction term in this model was significant because there was a positive relationship between macaroni penguin abundance and Antarctic krill

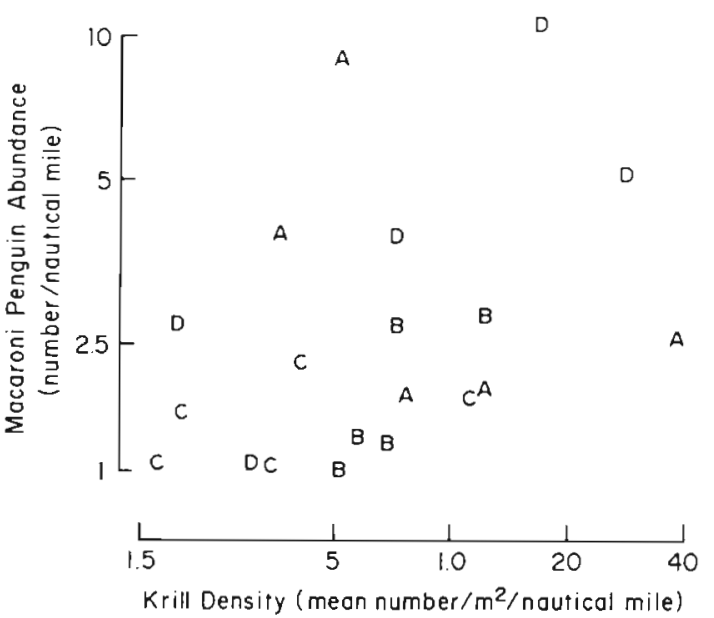

Fig. 3. Relationship between the mean abundance of macaroni penguins and Antarctic krill in Survey 1 at the scale of whole radials. Each point is a mean for a whole radial, and is denoted with the letter of the sector to which it belonged. Data are plotted on $\log _{10}$ scales. Note that the 5 radial means in sector $A$ show a negative correlation, whereas the others show a positive correlation

density in sectors $B$ to $D$, but a negative relationship in sector A (Fig. 3).

For Antarctic fur seals, the predator-prey correlations (see Table 5) suggest that the strongest prey tracking occurred over the scales of radials to fifths of radials. However, distance was a potentially confounding factor at the smaller scales, because a decline in predator abundance with distance from colony is expected for a central place forager even if no prey tracking occurs, and because the density of Antarctic krill also decreased with distance from the colonies. Nonetheless, Antarctic krill density remained a highly significant predictor of Antarctic fur seal abundance when the effect of Distance was removed (ANCOVA: Distance, $\mathrm{df}=4, \mathrm{p}=0.001$; Krill, $\mathrm{df}=1, \mathrm{p}<0.001$; error, $\mathrm{df}=92$ ). This correlation between Antarctic fur seals and Antarctic krill primarily occurred in the first 3 distance categories (18 to $74 \mathrm{~km}$; Fig. 4).

Shelf-Slope effects. With the effects of Direction and Distance controlled for, Depth-Realm did not explain a significant proportion of the variance in the abundances of either of the predators or the prey (Table 3 ).

Depth. With the effects of Direction and Distance controlled for, water Depth explained a significant proportion of the variance in Antarctic fur seal and Antarctic krill abundances (Table 4). For Antarctic krill, this relationship was due to a tendency for more krill to be found on radials over deeper water in each of the 5 distance rings. The same relationship was true for Antarctic fur seals, except for the outermost distance ring in which no relationship to depth was found. 


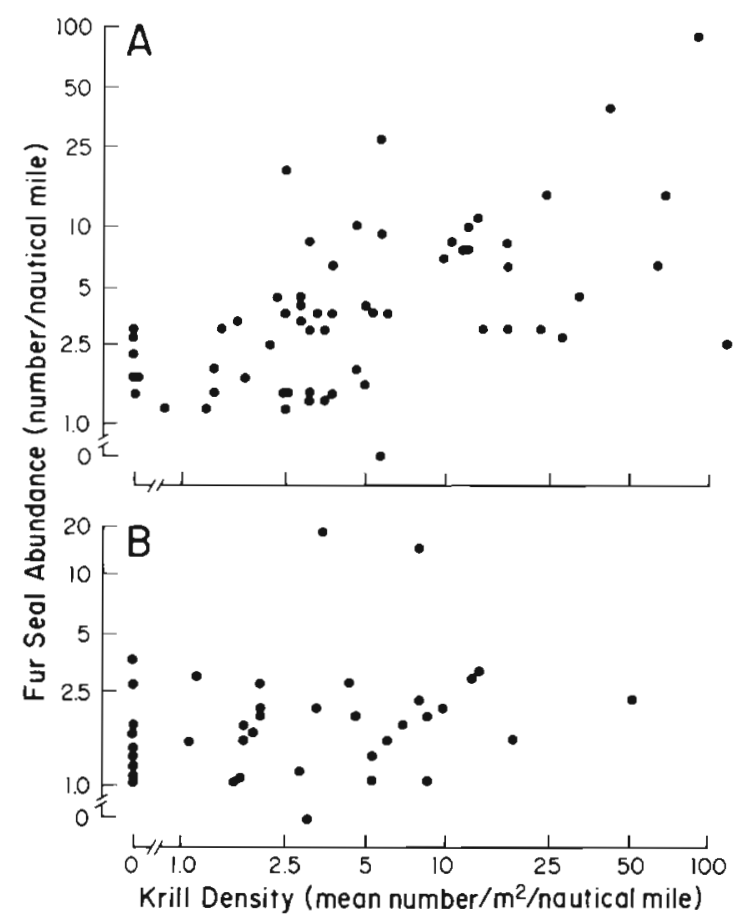

Fig. 4. Relationship between Antarctic fur seal abundance and Antarctic krill density during Survey 1 in (A) the first 2 distance intervals and (B) the outer 3 distance intervals. Points are distance-interval means for each radial. Data are plotted on $\log _{10}$ scales

\section{Survey 2}

Survey 2 of our study provided the opportunity for a second examination of the factors influencing the distributions of krill and predators (Fig. 5). Although the 2 surveys covered much the same area, Survey 2 radials came closer inshore, where Antarctic krill was abundant during Survey 1. Therefore, direct comparisons of

Table 3. ANOVAs of ranked mean predator and prey abundances as a function of Direction, Distance, and Depth-Realm ( 3 levels) during Survey 1 . Dependent values were the ranks of mean abundances within each of the 3 depth realms along each of the 5 radials within each of the 4 sectors $(n=52$, 8 radials terminated over the shelf). No interactions were significant

\begin{tabular}{|c|c|c|c|c|}
\hline \multirow[t]{2}{*}{ Factor } & \multirow[t]{2}{*}{ df } & \multicolumn{3}{|c|}{$p$-value } \\
\hline & & $\begin{array}{c}\text { Macaroni } \\
\text { penguin }\end{array}$ & $\begin{array}{l}\text { Antarctic } \\
\text { fur seal }\end{array}$ & $\begin{array}{c}\text { Antarctic } \\
\text { krill }\end{array}$ \\
\hline Direction & 3 & 0.05 & 0.27 & 0.03 \\
\hline Distance & 1 & 0.73 & 0.24 & 0.61 \\
\hline Depth-Realm & 2 & 0.11 & 0.57 & 0.57 \\
\hline Error & 45 & & & \\
\hline Model $\mathrm{R}^{2}$ & & 0.51 & 0.42 & 0.25 \\
\hline
\end{tabular}

Table 4. ANCOVAs of ranked mean predator and prey abundances as a function of Direction, Distance, and Depth during Survey 1. As before, Direction and Depth were categorical factors. Depth was a linear covariate with its values being the mean depth in a given distance interval on a given radial. No interactions were significant

\begin{tabular}{|c|c|c|c|c|}
\hline \multirow[t]{2}{*}{ Factor } & \multirow[t]{2}{*}{$\mathrm{df}$} & \multicolumn{3}{|c|}{$p$-value } \\
\hline & & $\begin{array}{l}\text { Macaroni } \\
\text { penguin }\end{array}$ & $\begin{array}{l}\text { Antarctic } \\
\text { fur seal }\end{array}$ & $\begin{array}{c}\text { Antarctio } \\
\text { krill }\end{array}$ \\
\hline Direction & 3 & $<0.001$ & 0.15 & 0.35 \\
\hline Distance & 4 & 0.004 & $<0.001$ & $<0.001$ \\
\hline Depth & 1 & 0.115 & 0.003 & 0.002 \\
\hline Error & 89 & & & \\
\hline Model $\mathrm{R}^{2}$ & & 0.48 & 0.41 & 0.25 \\
\hline
\end{tabular}

krill and predator abundance between the 2 surveys must be made cautiously.

As in Survey 1, Antarctic krill was highly clustered close to the colony in the South, and more evenly distributed in the North. Again, macaroni penguin and Antarctic fur seal distributions paralleled this pattern. All 3 species' abundance distributions showed a highly significant dependence on Distance (Table 5), especially to the South, where abundances in the first distance interval were 1 to 2 orders of magnitude greater than in the outer intervals (Table 6). As in Survey 1, Antarctic fur seals were more abundant to the South. The greater overall density of Antarctic krill to the South was not statistically significant because of a very large variance among sampling units within each side in Survey 2.

To the North, the abundance of macaroni penguins decreased evenly with distance and showed no apparent response to the peaks in Antarctic krill density in the $2 \mathrm{nd}$ and 4 th distance intervals (Table 6). In contrast, the gross distribution of Antarctic fur seals closely matched that of Antarctic krill. However, these patterns were not reflected in the ANCOVA results because of high inter-radial variance (Table 7 ). To the South of the colony, almost all biomass of all 3 species was recorded in the 1 st distance interval. The very large difference in abundance of all 3 species in the 1st distance interval between the North and South (Table 6) was reflected in a strong relationship between Antarctic fur seal abundance and Antarctic krill density (Fig. 6), but not between macaroni penguins and Antarctic krill (Fig. 7). However, because these associations between the predators and krill occurred close to the island, where we expect large numbers of predators under any conditions, we were unable to detect any additional effect of Antarctic krill on the abundance of either predator with the effect of Distance removed (Table 7 ). 

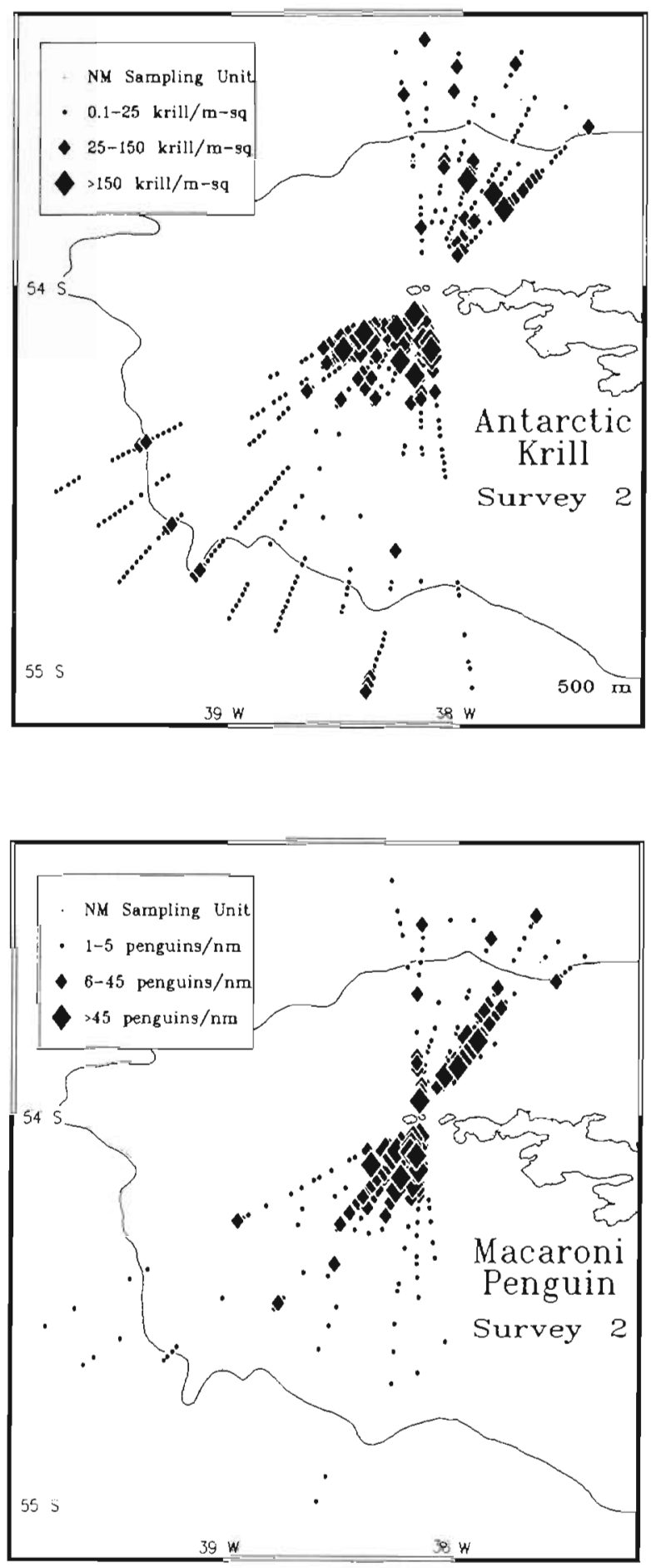

Evaluation of biases

We examined the possibility that several sources of bias might have influenced our study and reduced our ability to detect correlations between predators and their prey.

Krill depth. Eighty percent of Antarctic fur seal and

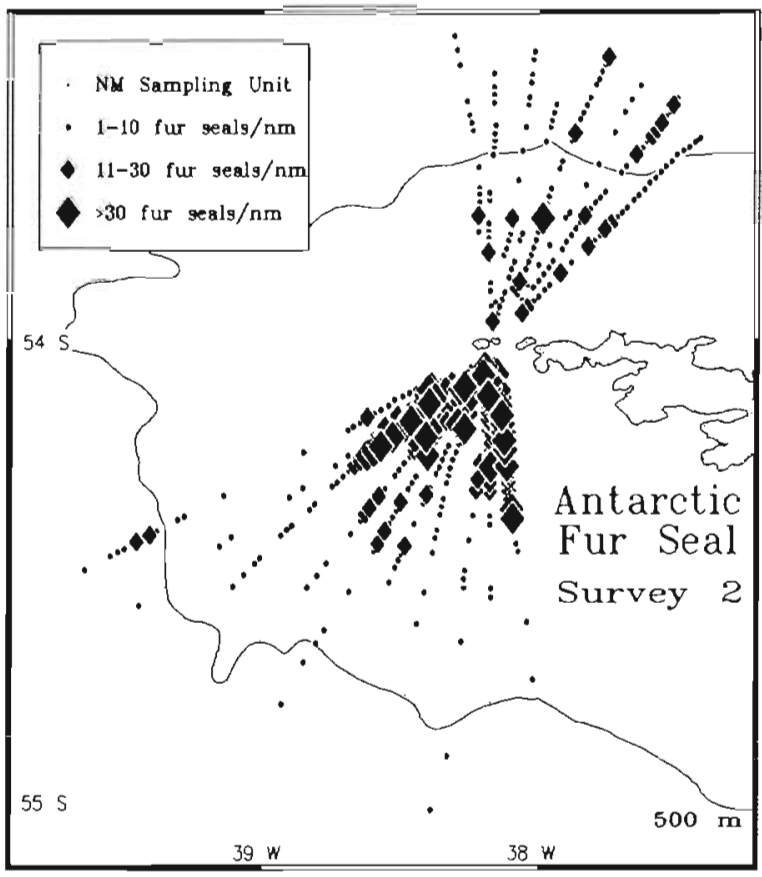

Fig. 5. Distribution maps of Antarctic krill and predators from Survey 2. See Fig, 2 for details

macaroni penguin dives are shallower than 40 to $60 \mathrm{~m}$ (Croxall et al. 1985b, 1988, J. P. Croxall pers. comm.). Therefore, we compared the strength of correlations between the abundances of krill and the 2 predators, for krill that was between 10 and $60 \mathrm{~m}$ deep, and for krill at greater than $60 \mathrm{~m}$ depth. Correlations for macaroni penguins were more often greater using the shal- 
Table 5. Nested ANOVAs of ranked mean predator and prey abundances as a function of Side ( $N$ vs $S$ ) and Distance (nested within Side, 4 levels) during Survey 2

\begin{tabular}{|c|c|c|c|c|}
\hline \multirow[t]{2}{*}{ Factor } & \multirow[t]{2}{*}{$d f$} & \multicolumn{3}{|c|}{ p-value } \\
\hline & & $\begin{array}{l}\text { Macaroni } \\
\text { penguin }\end{array}$ & $\begin{array}{c}\text { Antarctic } \\
\text { fur seal }\end{array}$ & $\begin{array}{c}\text { Antarctio } \\
\text { krill }\end{array}$ \\
\hline Side & 1 & 0.059 & 0.010 & 0.96 \\
\hline Distance & 6 & $<0.001$ & $<0.001$ & $<0.001$ \\
\hline Error & 63 & & & \\
\hline Model $\mathrm{R}^{2}$ & & 0.36 & 0.71 & 0.45 \\
\hline
\end{tabular}

low krill density (mean $\mathrm{r}=0.20$ ) than the deep krill density (mean $r=0.12$ ) (21 of 38 radials had stronger correlations with shallow krill\}, but the trend was not significant (1-sided Wilcoxon signed-rank test, $\mathrm{p}=$ 0.09). There was no evidence of a similar trend for the Antarctic fur seal correlations (mean $r$ with shallow krill 0.12 , with deep krill $0.13 ; 15$ radials with stronger $r$ value with shallow krill vs 23 radials with stronger $\mathrm{r}$ values for deep krill).

Time of day. Due to diel vertical migrations of krill, predators might be more closely correlated with krill when krill were near the surface early in the morning (before 06:30 $\mathrm{h}$ local time) and late in the day (after $18: 30 \mathrm{~h}$ ) than during the rest of the daylight hours. Correlations for both predators with Antarctic krill appeared stronger during midday than at dawn and dusk, although for neither predator was the mean difference statistically significant $(0.05$ vs 0.25 for macaroni penguins, -0.10 vs 0.2 for fur seals; for both species 1 -sided Wilcoxon matched sign test, $\mathrm{p}<0.5$ ). On 9 of 15 days, macaroni penguins showed a stronger correlation with Antarctic krill during midday than at dawn and dusk. Antarctic fur seals showed a higher correlation at midday on 11 of 15 days. We conclude that within the limits of the times of day we could test, time of day was not a significant influence on our ability to detect correlations between these predator species and krill.

Presence of non-feeding animals. Although we recorded behaviors such as 'sitting' or 'porpoising' (travelling/commuting) when we made observations of predators, in our main analyses we evaluated all animals seen. We found that only 10 of 35 correlations between macaroni penguins and Antarctic krill were stronger when only penguins that were sitting (not travelling) were used, and approximately half of the fur seal-krill correlations (18 of 38) were stronger when we included only those Antarctic fur seals that were not travelling. Average $r$ values for correlations between krill and sitting $(\mathrm{r}=0.16)$ or travelling $(\mathrm{r}=0.20)$ macaroni penguins were not significantly different (1sided Wilcoxon signed rank test, $\mathrm{p}>0.50)$. Likewise, for Antarctic fur seals, we found no significant differences using the same test $(p>0.50)$ for the correlations between krill and sitting fur seals ( $\mathrm{r}=0.12$ ) and travelling fur seals ( $r=0.16$ ). Thus, we conclude that combining data from all sightings of each of these predators did not obscure significant correlations between the predators and their prey.

\section{DISCUSSION}

In this study we found a strong persistence in the large scale distributions of Antarctic krill, macaroni penguins and Antarctic fur seals over the time period covered by the 2 surveys, particularly inshore on the south side of the island. In both Survey 1 and Survey 2, the distributions of these predators were similar to that of Antarctic krill, with the predators concentrated particularly in the vicinity of the large aggregations of krill close to the colonies. Our ability to detect statistically significant contributions by krill to the explained variance in preda-

Table 6. Mean abundances of predators and prey, and sampling effort during Survey 2, by Side and Distance from colony

\begin{tabular}{|c|c|c|c|c|c|}
\hline Side & $\begin{array}{l}\text { Distance } \\
(\mathrm{km})\end{array}$ & $\begin{array}{l}\text { Effort } \\
(\mathrm{km})\end{array}$ & $\begin{array}{c}\text { Macaroni penguins } \\
\left.\text { (no. } \mathrm{km}^{-1}\right)\end{array}$ & $\begin{array}{l}\text { Antarctic fur seals } \\
\left(\text { no. } \mathrm{km}^{-1}\right)\end{array}$ & $\begin{array}{l}\text { Antarctic krill } \\
\left(\text { no. } \mathrm{m}^{-2}\right)\end{array}$ \\
\hline \multirow[t]{5}{*}{ North } & 5 to 26 & 68 & 14.3 & 3.9 & 8.5 \\
\hline & 27 to 41 & 64 & 6.3 & 5.2 & 22.8 \\
\hline & 42 to 56 & 66 & 1.1 & 1.5 & 3.3 \\
\hline & 57 to 74 & 75 & 0.6 & 3.2 & 5.2 \\
\hline & Overall & 273 & 5.5 & 3.7 & 9.7 \\
\hline \multirow[t]{5}{*}{ South } & 3 to 37 & 146 & 21.2 & 26.7 & 54.1 \\
\hline & 38 to 65 & 146 & 0.5 & 3.7 & 1.7 \\
\hline & 66 to 93 & 150 & 0.2 & 0.5 & 1.9 \\
\hline & 94 to 118 & 125 & 0.3 & 0.2 & 6.5 \\
\hline & Overall & 567 & 5.6 & 8.0 & 16.3 \\
\hline
\end{tabular}


Table 7. ANCOVAs of ranked mean predator abundances as a function of Distance (4 levels) and ranked mean krill density (linear covariate) by Side during Survey 2

\begin{tabular}{|c|c|c|c|}
\hline \multirow[t]{2}{*}{ Factor } & \multirow[t]{2}{*}{$\mathrm{df}$} & \multicolumn{2}{|c|}{$\mathrm{p}$-value } \\
\hline & & $\begin{array}{c}\text { Macaroni } \\
\text { penguin }\end{array}$ & $\begin{array}{c}\text { Antarctic } \\
\text { fur seal }\end{array}$ \\
\hline \multicolumn{4}{|l|}{ North } \\
\hline Distance & 3 & 0.51 & 0.56 \\
\hline Krill & 1 & 0.63 & 0.39 \\
\hline Interaction & 3 & 0.63 & 0.36 \\
\hline Error & 23 & & \\
\hline Model $\mathrm{R}^{2}$ & & 0.26 & 0.32 \\
\hline \multicolumn{4}{|l|}{ South } \\
\hline Distance & 3 & 0.044 & 0.012 \\
\hline Krill & 1 & 0.63 & 0.36 \\
\hline Interaction & 3 & 0.078 & 0.70 \\
\hline Error & 23 & & \\
\hline Model $\mathrm{R}^{2}$ & & 0.52 & 0.81 \\
\hline
\end{tabular}

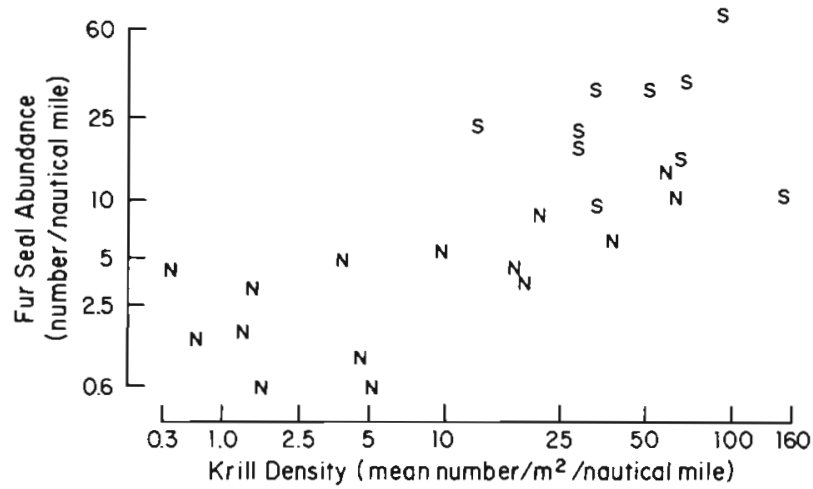

Fig. 6. Relationship between Antarctic fur seal abundance and Antarctic krill density close to the colony during Survey 2. Points are distance-interval means of the first 2 intervals on the North side (5 to $41 \mathrm{~km}$ from the colony) and the first interval on the South side ( 3 to $37 \mathrm{~km}$ from the colony), and are denoted with the side to which the interval belonged. Data are plotted on $\log _{10}$ scales

tor distributions, however, depended upon the scale at which correlations were sought, and were confounded by variables such as Distance from colony.

We found that, in general, both predator species showed a decrease in density with increasing distance from the colonies. This was not unexpected, both because of an expected dilution in numbers with increasing area, and because one would anticipate that, for energetic reasons, foraging would be concentrated inshore. An important exception to this pattern occurred on the north side of the colony, where there were peaks in the numbers of Antartic fur seals well offshore during both surveys.

Antarctic krill, like its predators, showed a strong

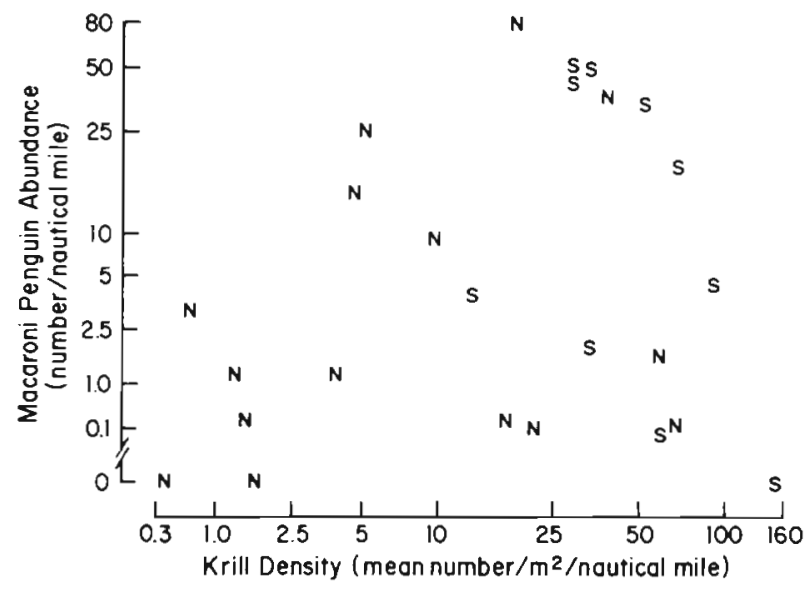

Fig. 7. Relationship between macaroni penguin abundance and Antarctic krill density close to the colony during Survey 2. Points are distance-interval means of the first 2 intervals on the North side (5 to $41 \mathrm{~km}$ from the colony) and the first interval on the South side ( 3 to $37 \mathrm{~km}$ from the colony), and are denoted with the side to which the interval belonged. Data are plotted on $\log _{10}$ scales

negative relationship between density and distance from colony. Priddle et al. (1988) suggested that krill may behave as passive particles in the mesoscale circulation of water, and it is possible that the krill distribution was the result of physical processes that, at the time of our surveys, produced the passive accumulation of large amounts of Antarctic krill close inshore. Regardless of the causative mechanism, because Antarctic krill were concentrated inshore, distance from the colony became a potentially confounding variable when we attempted to relate the distribution of predators to that of Antarctic krill. The data suggested a strong response to Antarctic krill by predators when the effect of distance was removed, but we were able to demonstrate a statistically significant effect only during Survey 1.

Although the possibility of Distance being a confounding variable was not unexpected for reasons given above, the reasons for Direction being an important source of explained variance is less clear. One possibility was that the predators selected a direction in which to depart from the colony based on where they last had success in finding prey, or the direction from which they observed successful foragers returning. Alternatively, Direction could reflect a response to some physical feature, such as current or wind direction, that we did not measure. Without being able to evaluate the causal relationship with Direction, to be conservative, we included it as a potentially confounding variable. We were still able to demonstrate a significant effect of krill density on predator abundance with the effects of Direction and Distance removed during Survey 1, but not Survey 2. 
Correlation analyses suggested that, with one exception, the numbers of predators and krill were positively related at scales from individual nautical miles to entire sectors. As in other studies (Obst 1985, Schneider \& Piatt 1986, Heinemann et al. 1989, Erikstad et al. 1990) correlations at small scales were weak, and increased with scale. Our analyses suggested that macaroni penguins were selecting foraging areas over scales ranging at least from sectors to whole radials. While we expected macaroni penguins to select foraging areas at smaller scales of approximately the size of a krill patch, we were unable to show such a relationship because the scale of $1 \mathrm{n}$ mile at which prey data were integrated was generally too large with respect to the size of most individual krill swarms (Miller \& Hampton 1989). By contrast, Antarctic fur seals showed tracking of Antarctic krill density from at least the scale of pairs of radials down to fifths of radials.

The weak correlations between the abundances of the 2 species of predators and krill, particularly at small spatial scales, may be underestimates because we could not consistently identify those predators that were feeding, we did not survey at night when many predators are feeding, and our measure of Antarctic krill density included krill that were not immediately available to predators and failed to include krill very close to the surface. However, when we examined the possible effects of these factors on our analyses, we failed to detect significant effects in our comparisons of predator-prey correlations made between (1) midday vs dawn and dusk, (2) sitting and porpoising predators, and (3) 'shallow' vs 'deep' krill. In addition, previous work by Everson (1983) suggested that relatively small amounts of Antarctic krill were likely to have been available in the top $10 \mathrm{~m}$ of the water column during our surveys, and thus this potential source of bias was likely to have been relatively unimportant. Occasionally krill is present near the surface (e.g. Harrison et al. 1991), but daytime foraging on krill by surface foraging birds is a relatively rare event, suggesting that, at least around South Georgia, diel vertical migrations of krill result in most krill residing below $10 \mathrm{~m}$ depth during daytime. We conclude that our results conservatively reflect the degree of association between these predators and their prey at the spatial scales we investigated.

Examination of the results of studies that have attempted numerical correlations between seabirds and their prey shows that prey type may influence the strength of correlation (Table 8). Prey that form discrete patches, particularly those that might be identified from the air, are better predictors of predator density than are prey that form more diffuse patches or meta-patches. Thus, predator numbers are more strongly correlated with debris from surfacing whales, capelin schools, and surface-swarming euphausiids than they are with krill

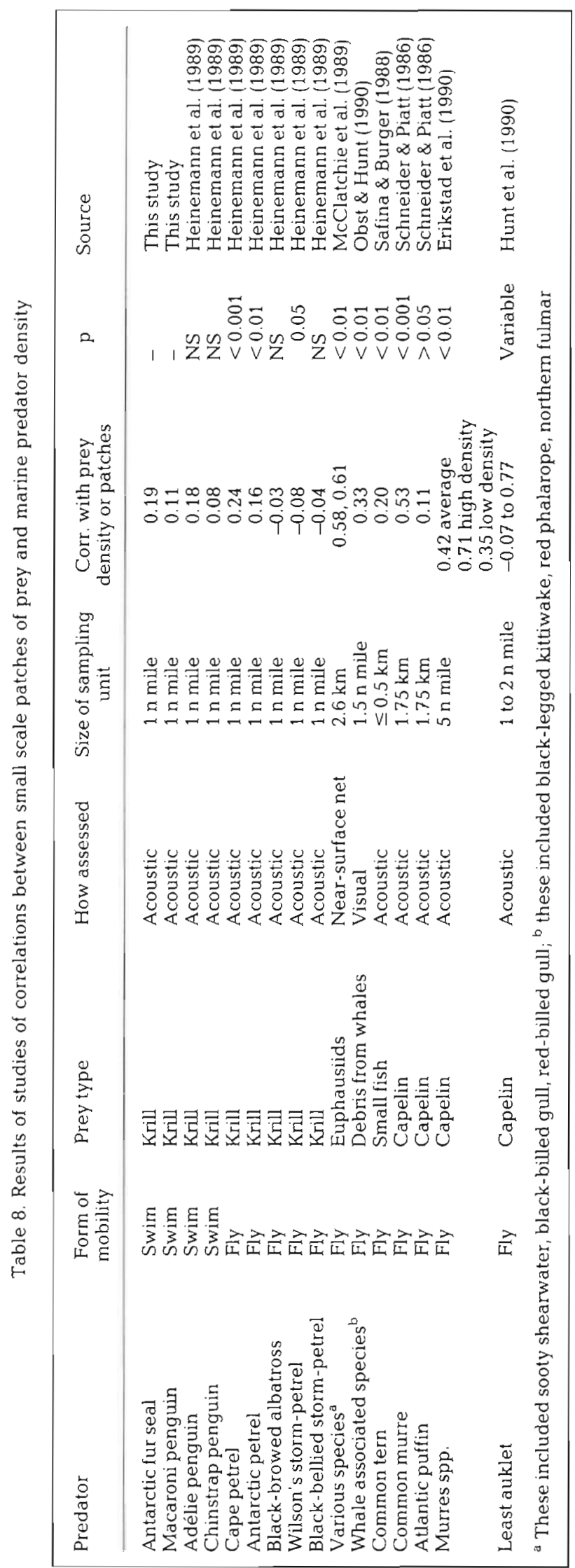


aggregations and, in some but not all cases, with copepod patches. The discreteness of patch boundaries (steepness of gradient) may be important for detection of prey patches by predators, particularly if patches are small (Elphick \& Hunt unpubl.). In addition, recent developments in geographical statistics suggest that habitat selection by organisms is likely to be sensitive to the size and spatial distribution of patches ( $O^{\prime}$ Neill et al. 1988, Milne et al. 1989, Milne 1992). For instance, our finding and that of others that correlations between predators and prey increase with the spatial scale of the sampling unit is similar to the prediction of O' Neill et al. (1988) that organisms should operate at larger scales for resource utilization when they perceive their resources as being sparse. In addition, large patches are more likely to be used than small, isolated patches of equal quality (Milne et al. 1989), and in some studies of marine birds, extremely large patches of prey have been the most important foraging areas, as judged by the proportion of all foraging birds seen throughout a study that attended them (e.g. Veit \& Hunt in press, Hunt et al. unpubl.). Concommitantly, relatively poor habitat adjacent to good patches has a probability of being occupied that is greater than that predicted solely on the basis of the habitat's quality (Milne et al. 1989). The expectation resulting from these models is that there will be a poorer fit between predator and prey numbers than would be expected on the basis of ideal free distribution models of patch selection (see Kacelnik et al. 1992 for a review).

An additional variable of possible interest is the predator's mode of search. Predators that swim while searching (e.g. seals, penguins) may have good ability to locate subsurface prey over very short distances, but they are likely to have difficulty detecting distant groups of feeding animals (but see Pierotti 1988 for examples of marine mammals using seabirds as guides). In contrast, birds that fly while searching for patches probably fail to detect sub-surface clues to the presence of prey patches, but are likely to have good success at obtaining clues about the presence of prey from observing other predators (e.g. Hoffman et al. 1981, Safina \& Burger 1985, Hunt et al. 1990, Hamison et al. 1991). In the present study, the search radius of the swimming predators may have been too small and the cost of travel too great to allow these predators to localize their foraging at the largest patches of prey.

Because marine birds and mammals are frequently found in dense concentrations near continental shelf edges (Brown 1980), we had anticipated that the continental-slope zone might be an area of concentration for predators and their prey in the present study. However, we found little evidence of predators concentrating over the continental slope. Antarctic krill showed some evidence of concentration at or near the shelf edge of the South side, especially in Survey 2 (Figs. $2 \& 5$ ), but the relationship was not statistically significant in our analyses. In this system, at least in the 1986 season, the shelf edge was not an area of enhanced concentration for the predators analyzed here. Antarctic krill were more abundant on radials over deeper water within any given sector and distance interval. Antarctic fur seals followed this same pattern except in the outermost distance ring. Since there was little evidence for concentration of krill near the shelf-edge, it is unlikely that any of the potential sources of bias in our ability to detect associations of predators and krill had any influence on our findings concerning predator and prey use of the shelf-edge habitat.

Although the large-scale pattern was very similar in the 2 surveys of our study, which were separated by $20 \mathrm{~d}$, we have no reason to believe that the particular spatial distribution of Antarctic krill observed during our surveys is the most usual pattern. Whale-catch records from the first half of this century indicate that Antarctic krill has been most abundant over the continental shelf north of South Georgia in most years, and only occasionally more abundant to the south (Harmer 1931, Hardy \& Gunther 1935, Everson 1984). Macaroni penguins and Antarctic fur seals that were radio collared on Bird Island prior to 1986 were found to depart on foraging trips mostly to the northwest ( $\mathrm{J}$. P. Croxall pers. comm.). Our data indicate that in 1986 there was a larger concentration of Antarctic krill close inshore to the south of Bird Island than to the north during Survey 1 and the first part of Survey 2. Based upon historical patterns of foraging predators, a predominance of Antarctic krill to the south of Bird Island is an uncommon occurrence.

Our study demonstrates not only the use of large inshore concentrations of Antarctic krill, but also the extensive use of offshore foraging areas by breeding macaroni penguins and Antarctic fur seals. Of the Antarctic fur seals and macaroni penguins counted during Survey 1, approximately $75 \%$ of each occurred on the inner halves ( 18 to $56 \mathrm{~km}$ from the colony) of the radials. However, extrapolation of our abundance estimates to the entire study area suggested that only $50 \%$ of the Antarctic fur seals and $57 \%$ of the macaroni penguins at sea at any given time were between 18 to $56 \mathrm{~km}$ from the center. Because it is likely that a significant proportion of these birds were in transit to and from foraging sites, the offshore areas may be more important foraging grounds than is suggested by the distribution of densities we recorded.

Acknowledgements. We thank the captain, officers and crew of the RRS 'John Biscoe' for support in the field. Nancy Harrison, Richard Veit, Michael Whitehouse and numerous British Antarctic Survey scientists assisted in the collection of data. Chris Ricketts aided in sampling design. Catherine Mitchell and Andy Wood assisted in data management and 
analysis. We thank J. P. Croxall, D. C. Schneider, R. Veit and E. Woehler for helpful comments on an earlier version of the manuscript. Financial support was provided by the Natural Environment Research Council to the British Antarctic Survey, and by National Science Foundation Grant number DPP8318464 to G. L. Hunt.

\section{LITERATURE CITED}

Ainley, D., Jacobs, S. S. (1981). Sea-bird affinities for ocean and ice boundaries in the Antarctic. Deep Sea Res. 28A: 1173-1185

Au, D. W K., Pitman, R. L. (1986). Seabird interactions with dolphins and tuna in the eastern tropical Pacific. Condor 88: $307-317$

BIOMASS (1986). Biological Investigations of Marine Antarctic Systems and Stocks, report on Post-FIBEX Acoustic Workshop, Frankfurt, September 1984

Bonner, W. N. (1981). Southern fur seals. Arctocephalus (Geoffroy Saint-Hilaire and Cuvier, 1826). In: Ridgeway, S. H., Harrison, R. J. (eds.) Handbook of marine mammals Academic Press, London, p. 161-208

Brodie, P. F., Sameoto, D. D., Sheldon, R. W. (1978). Population densities of euphausiids off Nova Scotia as indicated by net samples, whale stomach contents, and sonar. Limnol. Oceanogr 23: 1264-1267

Brown, R. G. B. (1980). Seabirds as marine animals. In: Burger, J., Olla, B., Winn, H. E. (eds.) Behavior of marine animals, Vol. 4, Marine birds. Plenum Press, New York, p. 1-39

Conover, W. J. (1980). Practical nonparametric statistics. Wiley \& Sons, New York

Croxall, J. P., Prince, P. A. (1981). A preliminary assessment of the impact of seabirds on marine resources at South Georgia. Colloque sur les ecosystèmes subantarctiques. 1981, Paimpoint, C.N.F.R.A. 51 501-509

Croxall, J. P., Ricketts, C., Prince, P. A. (1984a). Impact of seabirds on marine resources, especially krill in South Georgia waters. In: Whittow, G. C., Rahn, H. (eds.) Seabird energetics. Plenum Press, New York, p. 285-317

Croxall, J. P., Prince, P. A., Hunter, I., McInnes, S. J., Copestake, P. G. (1984b). The seabirds of the Antarctic Peninsula, islands of the Scotia Sea, and Antarctic Continent between $80^{\circ} \mathrm{W}$ and $20^{\circ} \mathrm{W}$ : their status and conservation. In: Croxall, J. P., Evans, P. G. H., Schreiber, R. W (eds.) Status and conservation of the world's seabirds. Int. Counc for Bird Preserv., Tech. Pub. No. 2, Cambridge, UK, p. $637-666$

Croxall, J, P., Prince, P. A., Ricketts, C. (1985a). Relationships between prey life-cycles and the extent, nature and timing of seal and seabird predation in the Scotia Sea. In: Siegfried, W.R., Condy, P. R., Laws, R. M. (eds.) Antarctic nutrient cycles and food webs. Springer-Verlag, Berlin, p. 516-533

Croxall, J. P., Everson, I., Kooyman, G. L., Ricketts, C., Davis, R. W. (1985b). Fur seal diving behaviour in relation to vertical distribution of krill. J. Anim. Ecol. 54: 1-8

Croxall, J. P., Davis, R. W., O'Connell, M. J. (1988). Diving patterns in relation to diet of Gentoo and Macaroni penguins at South Georgia. Condor 90: 157-167

Ensor, P. H., Shaughnessy, P. D. (1990). Fur seals over the Kerguelen Plateau and elsewhere in the Southern Ocean. Polar Biol. 10: 481-483

Erikstad, K. E., Moum, T., Vader, W. (1990). Correlations between pelagic distribution of Common and Brünich's Guillemots and their prey in the Barents Sea. Polar Res. 8: $77-87$
Everson, I. (1983). Variations in vertical distribution and density of krill swarms in the vicinity of South Georgia. Mem. nat. Inst. polar Res., Tokyo (Spec. Issue) 27: 84-92

Everson, 1. (1984). Marine interactions. In: Laws, R. M. (ed.) Antarctic ecology. Academic Press, London, p. 783-819

Everson, I., Bone, D. G. (1986). Effectiveness of the RMT8 system for sampling krill (Euphausia superba) swarms. Polar Biol. 6: 83-90

Everson, I., Watkins, J. L., Bone, D. G., Foote, K. G. (1990). Implications of a new acoustic target strength for abundance estimates of Antarctic krill. Nature, Lond. 345 : $338-340$

Foote, K. G., Everson, I., Watkins, J. L., Bone, D. G. (1990). Target strengths of Antarctic krill (Euphausia superba) at 38 and $120 \mathrm{kHz}$. J. acoust. Soc. Am. 87 16-24

Fraser, W. R., Pitman, R. L., Ainley, D. G. (1989). Seabird and fur seal responses to vertically migrating winter krill swarms in Antarctica. Polar Biol. 10: 37-41

Furness, R. W., Birkhead, T. R. (1984). Seabird colony distributions suggest competition for food supplies during the breeding season. Nature, Lond. 331: 655-656

Gaston, A. J., Chapdelaine, G., Noble, D. G. (1983). The growth of thick-billed murre chicks at colonies in Hudson Strait: inter- and intra-colony variation. Can. J. Zool. 61: $2465-2475$

Hamilton, W. J. III, Watt, K. E. F. (1970). Refuging. A. Rev. Ecol. Syst. 1. 263-297

Hardy, A. C., Gunther, E. R. (1935). The plankton on the South Georgia whaling grounds and adjacent waters, 1926-1932. 'Discovery' Rep. 11: 1-456

Harmer, S. F. (1931). Southern whaling. Proc. Linn. Soc. Lond. 142: 85-163

Harrison, N. M., Whitehouse, M. J., Heinemann, D., Prince, P. A., Hunt, G. L., Veit, R. R. (1991). Observations of multispecies seabird flocks around South Georgia. Auk 108: 801-810

Heinemann, D., Hunt, G. L., Everson, I. (1989). Relationships between the distributions of marine avian predators and their prey, Euphausia superba, in Bransfield Strait and southern Drake Passage, Antarctica. Mar. Ecol. Prog. Ser. 58: 3-16

Hoffman, W., Heinemann, D., Wiens, J. A. (1981). The ecology of seabird foraging flocks in Alaska. Auk 98: 437-456

Hunt, G. L. (1990). The pelagic distribution of marine birds in an heterogeneous environment. Polar Res. 8: 43-54

Hunt, G. L., Harrison, N. (1990). Foraging habitat and prey taken by least auklets at King Island, Alaska. Mar. Ecol. Prog. Ser. 65: 141-150

Hunt, G. L., Schneider, D. C. (1987). Scale-dependent processes in the physical and biological environment of marine birds. In: Croxall, J. P. (ed.) Seabirds, feeding ecology and role in marine ecosystems. Cambridge University Press, Cambridge, p. $7-41$

Hunt, G. L., Eppley, Z. A., Schneider, D. C. (1986). Reproductive performance of seabirds: the importance of population and colony size. Auk 103: 306-317

Hunt, G. L., Harrison, N. M., Cooney, T (1990). The influence of hydrographic structure and prey abundance on foraging of least auklets. Stud. Avian Biol. 14: 7-22

Kacelnik, A., Krebs, J. R., Bernstein, C. (1992). The ideal free distribution and predator-prey populations. Trends Ecol. Evol. (TREE) 7: 50-55

Kooyman, G. L., Davis, R. W., Croxall, J. P. (1986). Diving behavior of Antarctic fur seals. In: Gentry, R. L., Kooyman, G. L. (eds.) Fur seals: maternal strategies on land and at sea. Princeton University Press, Princeton, p. 115-125

Laws, R. M. (1977). The significance of vertebrates in the 
Antarctic marine ecosystem. In: Llano, G. A. (ed.) Adaptations within Antarctic ecosystems. Smithsonian Institution, Washington, D.C., p. 411-438

Laws, R. M. (1984). Seals. In: Laws, R. M. (ed.) Antarctic ecology. Academic Press, London, p. 621-715

Mackintosh, N. A. (1965). The stocks of whales. Fishing News (Books) Ltd., London

Makarov, R. R., Maslennikov, V. V., Solyankin, E. V., Spiridonov, V. A., Yakovlev, V. N. (1988). Variability in population density of Antarctic krill in the western Scotia Sea in relation to hydrological conditions. In: Sahrhage, D. (ed.) Antarctic ocean and resources variability. SpringerVerlag, Berlin, p. 231-244

McClatchie, S., Hutchinson, D., Nordin, K. (1989). Aggregation of avian predators and zooplankton prey in Otago shelf waters, New Zealand. J. Plankton Res. 11: 361-374

Milinski, M., Parker, G. A. (1991). Competition for resources. In: Krebs, J. R., Davies, N. B. (eds.) Behavioural ecology: an evolutionary approach, 3rd edn. Blackwell, London, p. $137-168$

Miller, D. G. M., Hampton, I. (1989). Krill aggregation characteristics: spatial distribution patterns from hydroacoustic observations. Polar Biol. 10: 125-134

Milne, B. T. (1992). Spatial aggregation and neutral models in fractal landscapes. Am. Nat. 139: 31-57

Milne, B. T., Johnston, K., Forman, R. T. T. (1989) Scaledependent proximity of wildlife habitat in a spatiallyneutral Bayesian model. Landscape Ecol. 2: 101-110

Nerini, M. (1984). A review of grey whale feeding ecology. In: Jones, M. L., Swartz, S. L., Leatherwood, S. (eds.) The grey whale, Eschrichtius robustus. Academic Press, New York, p. $423-450$

Obst, B. S. (1985). Densities of Antarctic seabirds at sea and the presence of the krill Euphausia superba. Auk 102: $540-549$

Obst, B. S., Hunt, G. L. Jr (1990). Marine birds feed at Gray Whale mud plumes in the Bering Sea. Auk 107: 678-688

Oliver, J. S., Slattery, P. N., Silberstein, M. A., O'Connor, E. F. (1984). Grey whale feeding on dense ampeliscid community near Bransfield, British Columbia. Can. J. Zool. 62: $41-49$

O'Neill, R. V., Milne, B. T., Turner, M. G., Gardner, R. H (1988). Resource utilization scales and landscape pattern Landscape Ecol. 2: 63-69

Orians, G. H., Pearson, N. E. (1979). On the theory of central place foraging. In: Horn, D. J., Stairs, G. R., Mitchell, R. D. (eds.) Analysis of ecological systems. Ohio State University Press, Columbus, p. 154-177

Pierotti, R. (1988). Associations between marine birds and mammals in the northwest Atlantic Ocean. In: Burger, J. (ed.) Seabirds and other marine vertebrates. Columbia Univ. Press, New York, p. 31-58

Plötz, J., Weidel, H., Bersch, M. (1991). Winter aggregations of

This article was presented by D. C. Schneider, St. John's Nfld, Canada marine mammals and birds in the northeastern Weddell Sea pack ice. Polar Biol. 11: 305-309

Powers, K. D., Brown, R. G. B. (1987). Seabirds. In: Backus, R. H. (ed.) Georges Bank, M. I. T. Press, Cambridge, p. $359-371$

Priddle, J., Croxall, J. P., Everson, I., Heywood, R. B., Murphy, E. J., Prince, P. A., Sear, C. B. (1988). Long-term fluctuations in mesoscale density of krill - a discussion of possible causes. In: Sahrhage, D. (ed.) Antarctic ocean and resources variability. Springer-Verlag, Berlin, p. 169-182

Ribic, C. A., Ainley, D. G., Fraser, W. R. (1991). Habitat selection by marine mammals in the marginal ice zone. Antarctic Sci. 2: 181-186

Ryan, P. G., Cooper, J. (1989). The distribution and abundance of aerial seabirds in relation to Antarctic krill in the Prydz Bay region, Antarctica, during late summer. Polar Biol. 10: 199-209

SC-CAMLR (1990). Scientific Committee for the Conservation of Antarctic Marine Living Resources, Report of the Ninth Meeting of the Scientific Committee. SC-CAMLR-IX/4, Report of the Second Meeting of the Working Group on Krill, Leningrad USSR, 27 August to 3 September. Pardgraph 23

Safina, C., Burger, J. (1985). Common Tern foraging: seasonal trends in prey fish densities and competition with bluefish. Ecology 66: 1457-1463

Safina, C., Burger, J. (1988). Ecological dynamics among prey fish, bluefish, and foraging Common Terns in an Atlantic coastal system. In: Burger, J. (ed.) Seabirds and other marine vertebrates. Columbia Univ. Press, New York, p. $95-173$

Schneider, D. C., Piatt, J. P. (1986). Scale-dependent correlation of seabirds with schooling fish in a coastal ecosystem. Mar. Ecol. Prog. Ser. 32: 237-246

Stephens, D. W., Krebs, J. R. (1986). Foraging theory. Princeton Univ. Press, Princeton

Updegraff, G. E., Hunt, G. L. (1985). Field use of microcomputers for the collection of seabird data. Pacific Seabird Group Bulletin 12: 19

Veit, R. R., Hunt, G. L. (in press). The spatial dispersion of seabirds near the South Orkney Islands and the WeddellScotia Confluence. Polar Biol.

Whittam, T. S., Siegel-Causey, D. (1981a). Species incidence functions in Alaskan seabird colonies. J. Biogeo. 8: 421-425

Whittam, T. S., Siegel-Causey, D. (1981b). Species interactions and community structure in Alaskan seabird colonies. Ecology 62: 1515-1524

Wilkinson, L. (1986). SYSTAT the system for statistics. SYSTAT, Evanston, IL

Woodby, D. (1984). The April distribution of murres and prey patches in the southeastern Bering Sea. Limnol. Oceanogr. 29: $181-188$

Manuscript first received: June 12, 1991

Revised version accepted: May 22, 1992 